\title{
Adapting an Undergraduate Multiliteracies German Curriculum FOR ONLINE INSTRUCTION DURING THE COVID-19 PANDEMIC
}

\author{
Adaptación de un CurRículo de alemán basado EN PEDAgogía \\ DE LAS MULTILITERACIDADES PARA LA INSTRUCCIÓN EN LÍNEA A ESTUDIANTES \\ UNIVERSITARIOS DURANTE LA PANDEMIA DE COVID-19
}

ADAPTATION D'UN PROGRAMME DE LANGUE ALLEMANDE SUR L'APPROCHE DE MULTILITTÉRATIES POUR L'ENSEIGNEMENT EN LIGNE D'ÉTUdiANTS D'UNIVERSITÉ PENDANT LA PANDÉMIE DE COVID-19

\section{Joseph Cunningham}

Assistant Professor, Department of German, Georgetown University, Washington, D.C., USA joe.cunningham@georgetown.edu https://orcid.

org/0000-0002-0551-1307

\begin{abstract}
This article reports on the adaptation of an undergraduate German curriculum for a distance language education (DLE) context. Understanding that DLE has evolved over the course of decades, the article reviews literature describing pedagogical and technological developments that are fundamental to understanding current practices in DLE. Against this backdrop, a detailed methodology is presented that explains the pedagogical practices that were adopted and adapted following the pandemic-induced shift from classroom-based teaching to DLE. Special attention is devoted to the role of synchronous instruction, as well as asynchronous tools that support multiliteracies instruction. The article concludes by considering those curricular innovations that are likely to have a long-lasting impact on the delivery of instruction following a return to classroom-based teaching.
\end{abstract}

Keywords: distance language education; online instruction; ICT; multiliteracies pedagogy; German instruction; teacher education; Covid-19; curricular adaptations.

\section{RESUMEN}

Este artículo reporta cómo se adaptó un plan de estudios de alemán en pregrado para la enseñanza a distancia. En el entendido de que la enseñanza de lenguas en línea tiene décadas de evolución, este artículo hace una revisión de la literatura que describe los desarrollos pedagógicos y tecnológicos básicos para comprender

Received: 2021-03-07 / Accepted: 2021-06-22 / Published: 2021-09-11

https://doi.org/10.17533/udea.ikala.v26n3a15

Special issue on The Role of Technology in Language Teaching and Learning amid the Crisis Generated by the COVID-19 Pandemic.

Editors: Marta González-Lloret, University of Hawai'i at Mānoa, usA; Laia Canals, Universitat Oberta de Catalunya, Spain; Jorge Pineda, Universidad de Antioquia, Colombia.

(C) 2021 Universidad de Antioquia. This is an open access article distributed under the terms of the Creative Commons License BY-NC-SA 4.0 International. 
las prácticas actuales de la enseñanza de lenguas a distancia. En este contexto, se presenta una metodología detallada que explica las prácticas pedagógicas adoptadas y adaptadas tras el cambio impuesto por la pandemia de la enseñanza presencial a la instrucción a distancia. Se presta especial atención al papel de la instrucción sincrónica, así como a las herramientas asincrónicas que soportan la instrucción basada en la pedagogía de las multiliteracidades. El artículo concluye con una consideración sobre las innovaciones curriculares que pueden tener un impacto duradero en la práctica pedagógica tras el retorno a la enseñanza presencial.

Palabras claves: enseñanza de lenguas a distancia; instrucción en línea; TIC; pedagogía de las multiliteracidades; instrucción en alemán; formación de docentes; COVID-19; adaptaciones curriculares.

\section{RÉSUMÉ}

Cet article rend compte de l'adaptation d'un programme d'études d'allemand de premier cycle à un contexte d'enseignement des langues à distance (DLE). Étant donné que l'enseignement de langues à distance a évolué au cours des décennies, l'article passe en revue la littérature décrivant les développements pédagogiques et technologiques qui sont fondamentaux pour comprendre les pratiques actuelles en DLE. Dans ce contexte, une méthodologie détaillée nous aide expliquer les pratiques pédagogiques qui ont été adoptées et adaptées à la suite du passage de l'instruction présentielle vers l'instruction à distance. Notamment on dévoue d'attention sur le rôle de l'apprentissage synchrone, ainsi qu'aux outils asynchrones qui étayent l'instruction multilittératie. Le rapport conclut en examinant les innovations curriculaires susceptibles d'avoir un impact durable sur la prestation de l'enseignement après un retour à l'enseignement en classe.

Mots clés : enseignement des langues à distance; instruction en ligne; TIC ; pédagogie des multilittératies; instruction en langue allemande; formation d'enseignants ; COVID-19, adaptations curriculaires. 


\section{Introduction}

In parallel with rapid developments in information and communications technologies (ICTs) during the previous two decades, distance language education (DLE) has also grown in both scale and availability. Whereas early efforts at DLE relied on print-based materials and the postal service, nowadays learners all over the world can take advantage of the multiplicity of options for communication and collaboration that are afforded by interactive and multimodal web-based environments. With the onset of the COVID-19 pandemic and the accompanying shift to DLE in many postsecondary contexts, there exists a new imperative to instill relevant skills and ways of thinking among pre-service and in-service teachers. At the same time, this episode invites us to examine our "techno-pedagogical competences" (Guichon \& Hauck, 2011, p. 191) with a critical eye, so that we are not simply replicating current instructional orthodoxy or reverting to outmoded pedagogies, but instead are approaching the use of technologies with an eye towards increased creativity and deepened student engagement.

In this light, the pandemic-induced shift to DLE presents a unique opportunity to examine one department's efforts to adjust its undergraduate curriculum so as to adapt to the exigencies of this new instructional landscape. Accordingly, this article will detail aspects of CALL teacher education in the Georgetown University German Department (GUGD), as well as curricular adaptations that resulted from an ongoing process of discussion and discernment. Moreover, with the prospect of students' imminent return to the physical classroom, there has begun a second reorientation: as we look towards the time when classroom instruction will once again be possible, it has become clear that curricular innovations resulting from the shift to DLE have strengthened aspects of the GUGD instructional approach pertaining to communication and collaboration amongst students and between students and instructors. As such, this article will also envision how a return to in-person teaching can benefit from the lessons learned during our time away from the physical classroom.

\section{The GUGD Undergraduate Curriculum}

In March 2020, faculty members and instructors of the GUGD received notice that all courses would henceforth be taught at a distance due to the rapidly worsening public health situation. Although the presence of COVID-19 in the United States had been established prior to this announcement, and whereas the GUGD had anticipated the possibility of a shift in instructional context, the actual transition to an online teaching environment took place with greater urgency, pushing the department to act swiftly and reactively. Initially, the GUGD turned to its instructional inclemency plan, which provides for the continued delivery of instruction using internet-based communication technologies (ICTs) during temporary-often weather-related-situations when physical access to the campus would no longer be possible. In the weeks and months that followed, the GUGD implemented a more proactive and systematic approach to adapting its multiliteracies curriculum for delivery in an online instructional environment. In order to understand this transition, it is first necessary to describe the nature of the undergraduate German program at Georgetown University.

The GUGD undergraduate program consists of a literacy- and genre-oriented, task-based curriculum. Courses are offered at five distinct levels: I-III (Introductory, Intermediate, Advanced) are sequenced and intended to be taken consecutively, whereas courses in Levels IV and v (Advanced + ) can be taken in order of preference, with the recommendation that at least one Level IV course be completed prior to taking Level $\mathrm{v}$ courses. In conjunction with language development, the curriculum emphasizes the development of humanistic knowledge (Cunningham et al., 2018) as an essential element of a liberal arts education, with the aim "to enable students to become competent and culturally literate users of German by combining a focus on content with carefully conceived pedagogical interventions 
that reflect the best available knowledge in classroom-based second language acquisition research" (Georgetown University, Department of German, 2020, "Curriculum" section). In order to understand how this goal is realized, I will first explain what is meant by the notion of (multi)literacy. Second, the role of tasks in the curriculum will be elucidated; in this regard, it will be important to see how the department ties these pedagogical interventions to the notion of genre. Lastly, given the central role of ICT in adapting the curriculum for DLE, it will be helpful to understand the role these technologies play in the program.

\section{A Pedagogy of Multiliteracies}

Drawing on Gee's (1998) distinction between primary discourse (i.e., language acquired by children in the context of their home and familial relationships) and secondary discourse(s) (i.e., language acquired and used in public settings, such as school, work, etc.), the GUGD curriculum seeks to develop multiliterate users of German. Whereas everyone (barring some sort of impediment to learning) is able to acquire the primary discourse of the language they hear at home, it is not the case that all speakers of a language are equally facile in secondary discourses. Literacy, if understood as control of secondary discourses (Gee, 1998), is therefore not an inevitable outcome for a speaker of any particular language and must be gained through an ongoing process of socialization, acculturation, and formal education. Noting the increasing range of communication contexts, especially in light of technological developments and the changing nature of work, the New London Group (1996) has called for a "pedagogy of multiliteracies" that is enacted through four pedagogical moves: critical framing, overt instruction, situated practice, and transformed practice (see also Cope $\&$ Kalantzis, 2009; Paesani et al., 2016). These pedagogical moves are instantiated in the GUGD curriculum through carefully designed courses at all curricular levels, wherein distinct instructional sequences culminate in a variety of speaking and writing tasks.

\section{Texts and Tasks}

Regardless of the level of instruction, all courses in the GUGD curriculum use as their central organizing principle the connection between text and task (Byrnes et al.,2006). Instructional units are designed around particular content themes, in which learners are exposed to texts of various modalities. As learners engage with texts through the pedagogical acts of multiliteracies instruction, they are led to understand how these texts are representative of particular genres in the way they are structured at the discourse, sentential, and even word level. This knowledge, together with careful preparation and detailed instructions, then scaffolds the learners as they appropriate the linguistics features of the focal text(s) to create their own texts that typify the genre (see also Crane, 2006).

In keeping with an understanding of genre as "staged, goal-oriented, purposeful activity in which speakers engage as members of a culture" (Martin, 1984, p. 25), task instructions are always presented in three parts: task, content, and language. The task section of the instruction sheet states the genre and mode (i.e., written or spoken) of the text, as well as providing additional details that help the writer or speaker to contextualize the text they are about to produce. The content section of the instruction sheet details the particular themes that should be present in the text, often making explicit connections to the text $(s)$ that the learners have engaged with prior to the introduction of the task. This section frequently features a list of questions that are designed to stimulate the learners' thinking on the topic and to ensure that relevant themes are addressed in a fulsome way. The language section of the instruction sheet provides specific linguistic features that should be present in the text at the discourse, sentence, and word level. Discourse-level features are often presented as speech acts (e.g., share an opinion, express gratitude, etc.) or socalled 'discourse markers' (i.e., short, fixed phrases such as "One the one hand...on the other hand") and generally help to focus the student's attention on the communicative purpose(s) of the text. 
Sentence-level features address language use at the clause level, often noting some particular word order or sentence structure that is genre typical. At the word level, students are encouraged to use thematically relevant vocabulary and are given guidance regarding the morphology of nouns, verbs, adjectives, etc.

\section{The Role of Technology}

Recognizing the importance of digital literacy as a component of a multiliteracies instructional framework, the GUGD has sought to integrate technologies that support expanded learning contexts. Chief among these efforts are a range of telecollaborative projects in upper-level courses, which have featured both synchronous text-based chat (RyshinaPankova, 2018), as well as synchronous audiovisual communication (Cunningham, 2019). Such virtual exchange projects even extend into our graduate program, where Master's and $\mathrm{PhD}$ students of the GUGD have connected with students at the University of Trier in Germany in order to select narrative texts and develop related teaching materials according to the principles of multiliteracies instruction (Cunningham \& Ryshina-Pankova, 2020). Here it bears once again emphasizing that it is chiefly the design of the tasks(s) in such digitally-mediated exchanges that will ensure their success (Blake, 2009). In addition to these projects, the undergraduate curriculum relies on a range of technologies that are now increasingly common in postsecondary education, including the learning management system (LMS) Canvas and various Web 2.0 applications (e.g., VoiceThread, Google Apps, etc.).

Having provided this brief overview of the GUGD program, we now turn to a discussion of DLE so as to better understand the changes that were made to the program and the outcome of those changes.

\section{Theoretical Framework}

The framework for the methodology proposed here is provided by distance language education and task-based language teaching.

\section{Distance Language Education}

DLE can be understood as planned learning that takes place in a context where there is spatial and/ or temporal distance between the teacher and learners, and which can entail a range of tasks, modalities, and technologies (Kraemer, 2008). Key to the evolution of DLE was the concurrent development of technologies that enabled the provision of instruction despite geographical distance (White, 2017). In other words, "technology has always been seen as an ally in maximising the benefits and counteracting some of the challenges of distance learning" (Hampel \& de los Arcos, 2013, p. 160).

One of the earliest postsecondary institutions to institute a broad and sustained effort at DLE was the Open University in the United Kingdom. Starting in the 1990s, the Open University sought to harness available technologies to enable geographically dispersed students to receive online instruction. Beginning with telephone conversations and progressing through computer-based text and audio chat to the present use of audiovisual voice-over-Internet protocol (VoIP), the overriding goal in using these technologies was to provide "opportunities for spoken interaction that [are] deemed essential for language development" (Hampel \& de los Arcos, 2013, p. 161). This perspective would prove prescient, as widening access and greater bandwidth soon contributed to a fundamental shift in the way individuals interacted with and through internet technologies. Whereas the nascent years of the World Wide Web were characterized by a passive transmission model with many consumers and few content creators, within a short amount of time, content creation and social interaction became the purview of any interested netizen. With the advent of social media, what we now refer to as Web 2.0 has become even more explicitly community oriented, with user interaction, group membership, and identity as core principles that motivate individuals to participate. 
With the shift to a more social and user-oriented Web 2.0, computer-mediated communication ( $\mathrm{CMC}$ ) and its attendant technologies have helped to connect learners and teachers for meaningful interaction in both asynchronous and synchronous modalities (Hampel, 2009). In addition to the critical role that CMC can play as the "glue" (Blake, 2005) that binds a class together, White (2017) notes that through CMC it has become increasingly "possible for distance language education to focus on communication and learning as a social process" (p. 134). The social process of learning is perhaps most clearly exemplified in the use of CMC as a gateway to language communities that extend beyond the course participants themselves. During so-called telecollaboration/virtual exchange, participants have the opportunity to engage directly with members of the target culture for language, culture, and content learning (Cunningham, 2016; Cunningham, 2019; Lewis \& O’Dowd, 2016).

As impressive as the technological developments are that make DLE possible, we must also bear in mind that such instructional environments necessitate concomitant "shifts in pedagogies...requiring both learners and teachers to rethink their practices" (White, 2017, p. 140). Accordingly, research has generated new insights regarding ways to maximize instructional effectiveness in this learning context. The ideal arrangement regarding teacher education in DLE involves a combination of technical and pedagogical training, the exact dimensions of which will depend on the experience level of the teachers (Hampel, 2009; Hampel \& de los Arcos, 2013; Hampel \& Stickler, 2005; Hubbard \& Levy, 2006; Guichon \& Hauck, 2011). Thus, the goal of teacher education in DLE should be that teachers have not only sufficient knowledge of information and communication technologies (ICTs), but they also should be able to engage creatively with these digital environments (Hampel, 2009; Hampel \& Stickler, 2005), as well as communicate their pedagogical functions to learners (Hampel \& de los Arcos, 2013).

Due to the lack of physical proximity in DLE, it is incumbent upon teachers to support student interaction and collaboration, with particular attention to social and affective factors that are unique to the computer-mediated environment. Centering student interaction becomes all the more critical due to the influence of the medium itself: "Despite the calls for learner autonomy and a transformed tutor role...online classroom settings (especially synchronous environments that allow for speaking) are often characterised by a tutorce(ntered approach to teaching" (Hampel, 2009, p. 36). Solutions for encouraging learner-centered teaching include putting teachers in the role of students, helping teachers understand proper task design, generating appropriate model tasks, and creating a space for reflection and sharing of experiences (Hampel, 2009). As a final consideration, successful teacher education for DLE requires the buy-in of its intended beneficiaries. It is not enough to mandate that such professional development should occur, but instead teacher educators should cultivate "an atmosphere where difficulties are not set aside but confronted and addressed, where in true socio-constructivist spirit everyone contributes their skills and knowledge" (Guichon \& Hauck, 2011, p. 190).

\section{DLE and Task-based Language Teaching}

The importance of proper task design in DLE cannot be overstated. Research of computer-assisted language learning (CALL) has long recognized the value of using tasks to foster language learning in both asynchronous CMC (Appel \& Gilabert, 2002; Hampel, 2006; Kitade, 2008; Lamy, 2006; Oskoz \& Elola, 2013; Yilmaz \& Granena, 2009) and synchronous CMC environments (Adams \& Nik, 2013; Cunningham, 2019; Collentine, 2009; Hampel, 2006; Jauregi, de Graff, van den Bergh, \& Kriz, 2012; Lamy, 2004; Levy \& Kennedy 2004; Oskoz \& Elola, 2013; Rosell-Aguilar, 2005). Given the longstanding and productive history 
of task-based approaches in researching CMC, González-Lloret \& Ortega (2014) argue for a well-considered fusion between Task-Based Language Teaching (TBLT) and CALL, identifying five key features of tasks in "technology-mediated TBLT": (a) a primary focus on meaning; (b) goal orientation; (c) learner-centeredness; (d) holism; and (e) reflective learning. By adhering to these features, one can productively integrate recognized task design principles that foster language development with appropriate technologies that support learning in DLE contexts.

To sum up, the past decades have witnessed explosive growth in ICTs. In parallel, language teachers-especially in the context of DLE have sought to leverage these new technologies to provide enhanced learning opportunities to their students. In particular, the rise of a more user-oriented Web 2.0 affords new opportunities for communication and collaboration amongst learners, between learners and teachers, and with speech communities extending well beyond the "walls" (be they physical or digital) of the classroom. In order to teach effectively in this new milieu, instructors must purposefully engage with relevant technologies, not only in order to understand their various pedagogical uses, but also so as to communicate to learners how to use these tools to make meaning in a second language. At all times, the integration of technology should be guided by sound pedagogical thinking wherein well-conceived tasks provide a means to engage learners and foster ongoing language development.

\section{From Here to There: The GUGD model of DLE}

Having discussed the salient features of DLE, I now explain the approach to DLE that has emerged in the GUGD. Rather than frame this discussion as a sequential process with discrete steps, it is perhaps more useful to conceive of this model in terms of its interrelations. As such, I will discuss the model in terms of the following non-sequential components: (a) needs analysis; (b) synchronous engagement; (c) asynchronous engagement; and (d) tasks.

Given the rapidity of the transition to distanced instruction, the GUGD - and indeed the university at large-was initially pushed into a reactive posture. Accordingly, the GUGD implemented its existing instructional continuity plan. This plan stipulates that in the event of an unforeseen closure to the campus, all classes are to be taught online using digital technologies. In practice, this policy had meant that when the university would shutter due to inclement weather, instructors had the means to connect with their students and teach the scheduled lesson without impacting the instructional sequence too severely. The instructional continuity plan had always been intended as a temporary answer to a temporary problem; it was not meant to serve as a long-term solution to a severe instructional disruption such as that caused by the pandemic. Moreover, the instructional continuity plan was not supported by ongoing and dedicated training. Rather, instructors were notified of the plan at pre-semester orientation meetings and advised to familiarize themselves with the relevant technologies. Given this state of affairs, the success of the instructional continuity plan was highly dependent on individual instructors' skills, training, and experience. It was clear that a more systematic approach would be necessary to ensure the delivery of high-quality language instruction at a distance.

\section{Component 1: Needs Analysis}

In keeping with the tenets of technology-mediated TBLT, one of the department's first moves in more purposefully implementing a DLE framework was to implement a process of needs analysis (González-Lloret, 2014). The aim of this process was not only to identify how best to support our students in this new instructional environment, but also to equip instructors with sufficient knowledge of those digital tools needed to successfully teach in a DLE environment. Most 
immediately, we had to ensure that both instructors and students had the necessary infrastructure to participate in synchronous instruction from their respective geographic locations. Once this basic need was met, we began a series of ongoing meetings (at a distance, of course) that all instructors were encouraged to attend. During these "Friday check-ins," we reflected upon successes and challenges in our teaching efforts, disseminated knowledge, shared effective practices, and identified new or ongoing needs of instructors and students. Additionally, in order to elicit the learners' perspectives, we invited all students enrolled in an undergraduate course to complete a questionnaire regarding the efficacy of instructional practices they had encountered in both their language classes and other courses they were enrolled in. In the same vein, we queried instructors as to their level of knowledge and the perceived value of various digital tools. Lastly, we encouraged instructors to attend any of a number of workshops, lectures, and teach-in events sponsored by the Center for New Designs in Learning and Scholarship at Georgetown University (https:// cndls.georgetown.edu/).

In sum, the initial weeks following the closure of the physical campus entailed a process of realignment that was informed by needs analysis and supported by university resources both within and outside the GUGD.

Through a continued process of discernment and reorientation during the remainder of the semester, the department was able to move from a more reactive to a more proactive posture. One outcome of this new footing was the implementation of a systematic and collaborative teacher education module following the end of spring term. Dubbed “The GUGD Summer Institute," this program was designed to provide in-service support for instructors who were teaching during the summer, but also to prepare instructors for the fall semester when all courses would be taught online for the duration of the entire semester. The overriding goal of the Summer Institute was to ensure a high level of multimodal digital literacy among instructors so that they were able to "represent meaning in more than one mode at a time, understand each mode and how to use different modes constructively, while remaining aware of...the affective demands of the new media" (Hampel $\&$ de los Arcos 2013, p. 168). In addition to the previously discussed needs analysis, the Summer Institute was informed by empirical research of DLE, especially as it pertains to teacher education, and which has been reviewed extensively in the background section of this article.

\section{Component 2: Synchronous Engagement}

For several reasons, the decision was made that the GUGD would, to the extent possible, maintain the existing teaching schedule through synchronous instruction via the audiovisual communications platform Zoom . First and foremost, understanding that affective factors can have an impact on learning and willingness to participate in DLE (Guichon, 2009; Hampel, 2009; White, 2017), the department felt that it was important to maintain regular synchronous contact with our students so as to give encouragement, monitor their emotional outlook, and provide an overall positive learning environment, especially during such a volatile and stressful period.

From an organizational perspective, the decision to maintain scheduled, synchronous instruction helped to ease disruptions to the curricular environment. Particularly in Levels I-III of the curriculum, the day-to-day focus of each lesson is tightly outlined through a series of unit plans; any deviation from these planned learning sequences can inhibit students' continued progress through the course and curriculum and are to be avoided when possible. Indeed, the very nature of these learning sequences lend themselves to adaptation for synchronous instruction. Since students of the GUGD are accustomed to learning in a "flipped" environment where out-of-class work serves to prepare them for active engagement during instructional periods, we were able to continue 
this approach via synchronous computer-mediated instruction. Finally, as the undergraduate curriculum serves as a locus for ongoing education of graduate student instructors, the use of synchronous instruction enabled this important aspect of teacher education to continue. To that end, graduate instructors whose classes would normally be visited by a more senior member of the GUGD could instead provide a recording of a lesson and receive feedback on it. In fact, the ability to view recorded teaching episodes affords opportunity for the provision of very detailed feedback to the instructors, often accompanied by actual clips of the instructors teaching. As Guichon (2009) argues, this kind of "self-confrontation produces a magnifying effect on crucial aspects of online teaching and draws trainees' attention to them" (p. 179).

Having established the rationale for implementation of a synchronous instruction model, it is important to describe the instructional environment in detail. The hub for all synchronous instruction was the audiovisual communications platform Zoom ${ }^{\circ}$. The typical Zoom ${ }^{\circ}$ room interface is a grid of "tiles" each showing a participant's video stream. In this interface, the active speaker has yellow highlighting around his/her tile, so that other participants can both see and hear who is speaking. This "gallery view" can be substituted by the "active speaker view," where the person who is currently speaking is shown in a comparatively larger tile. While participants had the option of not activating their video stream, learners of the GUGD were encouraged to show themselves if technical issues did not prevent it. Regardless of the selected view, and whether the participants show their video stream, Zoom also supports synchronous audio communication, so that students and instructors could communicate orally/aurally with one another.

In cases when audiovisual communication proved problematic or not feasible, instructors or students in a Zoom ${ }^{\circ}$ room could avail themselves of the chat function. Here, messages could be shared with all members of the class or directed more privately to individual participants. Additionally, Zoom ${ }^{\circledR}$ chat has other functionalities that support synchronous DLE. Since hyperlinks are fundamental to navigation of digital spaces, such links could be easily shared through the chat function. Even files of moderate size could be sent through the chat, easing the distribution of handouts and other learning materials.

Importantly, the chat also served as a space for learner-initiated side conversations. By posting a question or comment in the chat, learners could help one another to explore hypotheses, synthesize information, and generate additional questions without the direct intervention of the instructor. As such, the chat functionalities of Zoom ${ }^{\circ}$ supported both teacher-directed and learner-centered inquiry in DLE. It must be said, however, that the chat function also has the potential to distract, diverting instructor or student attention from information that is being shared via another modality. Additionally, it is important to orient correctly to the intended recipient of a chat message. Sending the wrong message to the wrong person has the potential to confuse or embarrass those involved, further distracting from the aims of the lesson.

A hallmark of learner-centered language instruction is the use of partner and small group work. Such learning configurations were also possible in the Zoom ${ }^{\circ}$ environment via the use of breakout rooms. Through random selection, host-selection, or self-selection, learners could be sorted into spaces that are "digitally adjacent" to the main room, enabling communication with one another and collaboration on tasks. The instructor could then move from breakout room to breakout room in order to monitor and assist. Unlike group work in the classroom, where everyone occupies the same physical space and group membership can be porous, Zoom-based groups are not in immediate contact with the instructor or other groups, so side conversations are less possible. As such, clear directions and modelling during the set-up phase were paramount. 
During actual group work in this environment, the teacher could set time limits when breakout rooms would automatically close or "broadcast" messages to all groups simultaneously. In turn, the learners could signal the teacher through the use of the help button, if necessary. Although the breakout rooms fulfilled their function as a space for smaller group work, it was only possible for the instructor to be present in one room at a time. As a result, it was sometimes the case that certain groups received more instructor attention than others or were unable to communicate their need for assistance to the instructor.

Due to the interconnection between text and task in the GUGD curriculum, substantial class time is devoted to scrutiny and analysis of texts. When it comes to written texts, it is often the case that an instructor will lead students through a detailed mark-up and annotation of a text in order for learners to understand how the generic stages of the text unfold and what linguistic features are present in the various stages of the text. Whereas textual analysis in classroom-based instruction occurs using a document camera and overhead projector, in the Zoom -based environment, the "screen share" function fulfilled this role. The instructor could show a document using word processing or text annotation software and elicit responses from the students through careful and deliberate questioning. The responses provided are added to the document in real time and are immediately visible to all students. In this way, the students' attention can be directed in a very deliberate way that contributes to a deep understanding of texts and the meanings they construe.

The screen share function was also used to support learner-centered engagement. For instance, learners could share their screens with one another during group work and then again with the whole class during presentations following group work. The exact dimensions of how the screen share function was utilized depended on the specific learning objectives, but a word of caution is in order. Many learners connect through a laptop or PC with only one monitor, and their screen space is consequently limited. When screen share is activated, the portion of usable screen space may be reduced as a result. Screen sharing should hence be deliberate, targeted and not continuously activated.

In classroom-based instruction, key information is often written down on a whiteboard or blackboard. In DLE, electronic means must be used to achieve this same effect. To that end, the GUGD adopted the use of Google Docs in order to replicate and expand upon the typical uses of the classroom whiteboard. Not only could instructors record notes on the shared class Doc, but the multimodal nature of Google Docs allowed for the integration of hyperlinks, visual information and other materials that support synchronous instruction. Used creatively, the shared class Doc also served as a locus for collaboration. When given editing permissions, students could write responses to questions directly on the Doc, while the instructor was able to provide immediate feedback through the comments function. For example, if students focused on construing meaning through particular linguistic forms, the instructor could leave a comment that notifies a learner when an incorrect form has been used, but then leave it up to the learner to make the correction herself. Conversely, if the focus of a particular task was on engaging with the content and themes of a text, then the instructor could leave comments for individual students that stimulate additional thinking or problematize simplistic responses. In such an environment, students could even direct comments or questions on their work to the instructor.

An additional advantage of using a shared class Doc is that it can reduce the need for screen sharing, which, as previously noted, has potential downsides. Instead, instructors could direct everyone to the Doc by sharing a link in the chat; class members' presence was indicated by 
both a distinct icon in the toolbar at the top of the Doc, as well as color-coded cursors that show where they currently were working in the Doc. A final advantage to using a digital white board via Google Docs is the perpetuity of the information. In other words, unlike a classroom-based whiteboard, the Google Doc does not get erased at the end of the class session. Instead, with every meeting the Doc grows in length, thereby serving as a record of the work that has been done in previous class sessions. This functionality enabled learners to review previous lessons easily, while also providing a sense of continuity to the course.

By the end of the term, the shared course Docs were quite lengthy; it is therefore advisable to use the built-in navigation features and instruct the learners in their use as well. If distinct headings are used for each class period, the app will automatically generate an outline of the Doc that can be viewed in an adjacent menu and navigated correspondingly.

Although the provision of synchronous instruction was a touchstone throughout the undergraduate curriculum, certain aspects did not always unfold smoothly. For example, despite our attempts to establish a baseline for technological requirements, some students still found themselves unable to participate equitably due to lagging internet speeds or other connectivity issues. This inequitable access to instruction serves as a warning that the infamous "digital divide" separating students based on region, socioeconomic status, or other factors did not automatically disappear because everyone started attending class online. As such, it became important for instructors to provide alternate means for connecting with students, including through asynchronous modalities or individualized synchronous meetings (i.e., office hours).

\section{Component 3: Asynchronous Engagement}

If an audiovisual platform like Zoom ${ }^{\oplus}$ serves as the hub for synchronous engagement, the asynchronous corollary would be a learning management system (LMS). The GUGD has utilized the LMS Canvas for a number of years now, but the platform took on newfound importance with the transition to DLE. Canvas has a range of built-in functions and integrates a number of third-party apps that help facilitate course organization and asynchronous pedagogical engagement. This flexibility means that documents, hyperlinks and other apps used for teaching and learning can be linked together into a larger ecosystem where learners are able to locate the necessary files or links that are required to complete their out-ofclass work.

Due to the ease with which Google Docs can be shared and collaborated upon, many GUGD instructors utilized this app in connection with out-of-class work. Using the "collaboration" function of Canvas, students completed their homework using a Doc that is shared only with the instructor.

This approach brought a number of advantages. Not only did it cut down on the degree of paper shuffling between students and teachers, but it supported collaboration in a way that was superior to paper-based homework. As previously noted, students and instructors can make productive use of the comments function of Google Docs while participating in synchronous instruction. This same function supported asynchronous communication between a learner and her instructor when completing out-of-class work. For instance, if a learner had a question or felt uncertain about a response, she could leave a comment for the instructor. The instructor could then respond to these comments, providing speedy and targeted help. In the same vein, an instructor could give unsolicited feedback that stimulates additional thinking or helps to clarify concepts.

These sorts of asynchronous activities ended up personalizing instruction to a degree that is simply not possible when students submit paper-based homework. On the other hand, such a set up led some instructors to feel less separation between 
in-class and out-of-class time, which resulted in increased levels of fatigue.

\section{Component 4: Tasks}

As previously discussed, the GUGD emphasizes the connection between text and task at all levels of the curriculum. Using the linguistic and discourse conventions of texts that have undergone previous analysis, learners complete a variety of writing and speaking tasks that are linked to specific genres. Whereas the completion of writing tasks was not greatly impacted by the shift to a DLE environment, the delivery of speaking tasks required significant adjustments.

Procedurally, the completion of writing tasks is a relatively straightforward affair. Students are given a detailed task sheet and compose their texts according to the guidelines given in three categories: task, content, and language. The completed texts are then submitted to the instructor, who gives feedback. In the case of linguistic infelicities, coded feedback indicates the presence and nature of an error, without providing actual corrections. It is then up to the learner to engage their metalinguistic awareness in order to address the coded feedback and submit a second draft of their text. In classroom-based instruction, students can submit either hard or e-copies of their writing tasks, depending on their instructor's preference. After beginning DLE, the only change to these procedures was that all writing tasks would be submitted electronically, and feedback would be provided via digital means.

Unlike writing tasks, the GUGD speaking tasks were originally designed to be completed live in class. These tasks are generally performed as a monologue by individual students or as a conversation between two or more students. Moreover, the performance of speaking tasks is often accompanied by a small listening task for members of the class who are acting as the audience. For example, in the second-semester course, Introductory German II, students give a short monologic presentation about one of the federal states of Germany, integrating specific content and language foci. While in the role of an audience member, students are expected to take notes about one of their classmates' presentations in order to write a paragraph in which they compare the federal state that they presented on with the federal state that their classmate presented on.

Although it would have been possible to preserve the live presentation of speaking tasks through synchronous means, the decision was made that such tasks could be productively adjusted for asynchronous distribution and consumption. In the case of most monologic speaking tasks, such as the aforementioned presentation of a federal state, students were instructed in the use of VoiceThread, a platform that allows participants to upload visual media as "slides" where audio comments can be recorded and played back. These slides can then be shared with the whole class, thereby preserving the related listener task. Alternately, certain speaking tasks (e.g., present a recipe for a television audience) may be better presented as a video recording. As it turns out, watching a video of students cooking in their kitchens while explaining recipes in German provided a far more authentic context than a VoiceThread or even classroombased presentation of the same activity! For conversation-based speaking tasks, fluent interaction between participants is a prerequisite. To enable this interaction, students recorded such speaking tasks in the $\mathrm{Zoom}^{\odot}$ environment. In essence, students created their own Zoom ${ }^{\circ}$ rooms, practiced the speaking task as many times as desired, and finally recorded themselves. These recordings were then disseminated to the instructor and other students via the LMS.

Given the additional procedural layers and technical capabilities required to complete speaking tasks through digital means, it is important to introduce the tools gradually and in a low-stakes way (Hampel, 2006). One way to do so is by setting up a "practice task" that familiarizes the students with the affordances of the technology. 
For example, in order to acquaint themselves with the content creation and sharing functionalities of VoiceThread, students in certain courses created and shared a brief self-introduction at the beginning of the term. These self-introductions were not assessed but supported affective aspects of instruction that are crucial in DLE. On a final note, by completing the speaking tasks in an asynchronous modality, class time that would have otherwise been dedicated to in-class performance became available for other instructional purposes.

While the use of asynchronous technologies helped to support the creation and delivery of monologic and dialogic speaking tasks, such was not the case when it came to group-based speaking tasks. For example, in Level III of the curriculum, students are increasingly pushed to use their language in public-facing genres via a number of "talk show"-style speaking tasks in which participants assume the role of prominent public figures. The Zoom ${ }^{\circ}$ environment, with its more regimented style of communication, was not an ideal environment for completion of such tasks because it did not support the fluid back-and-forth and overlapping speech that is common for the genre of talk show.

To summarize, the GUGD model of DLE (see Table 1) leverages ongoing needs analysis, research-informed teacher education, and a thoughtful blend of synchronous and asynchronous technologies to support the provision of instruction in a multiliteracies framework. Students collaborate and communicate with their classmates and instructors through regularly scheduled synchronous instruction. Students also use asynchronous technologies to complete outof-class work and to support their participation

Table 1 Components of the GUGD Model of DLE

\begin{tabular}{|c|c|c|}
\hline Component & Description & Tools used \\
\hline Needs analysis & $\begin{array}{l}\text { - confirm technical capacities, including Internet connectivity, for } \\
\text { instructors and students } \\
\text { - identify new and ongoing needs of instructors and students via } \\
\text { electronic questionnaires and discussion } \\
\text { - disseminate knowledge, share instructional practices, and reflect } \\
\text { upon successes and challenges via regular meetings } \\
\text { - implement tailored professional development module "The GUGD } \\
\text { Summer Institute" }\end{array}$ & 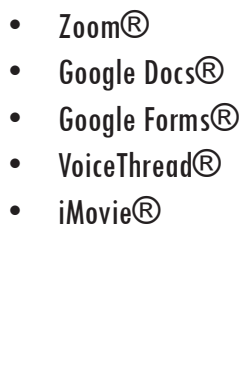 \\
\hline Synchronous engagement & $\begin{array}{l}\text { - } \text { maintain existing instructional schedule } \\
\text { - } \text { engage in iterative teacher education } \\
\text { - } \quad \text { pursue learner-centered instruction } \\
\text { - } \text { analyze texts functionally and critically } \\
\text { - integrate textual and graphic information } \\
\text { - } \quad \text { share and collaborate on electronic version of class notes }\end{array}$ & $\begin{array}{ll}\text { - } & \text { Zoom® } \\
\text { - } & \text { Google Docs }\end{array}$ \\
\hline $\begin{array}{l}\text { Asynchronous } \\
\text { engagement }\end{array}$ & $\begin{array}{l}\text { - } \quad \text { organize and deliver instructional materials } \\
\text { - } \text { engage in threaded discussion of relevant topics and themes } \\
\text { - } \quad \text { share, comment on, and revise out-of-class work }\end{array}$ & 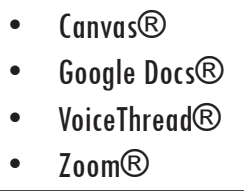 \\
\hline Tasks & $\begin{array}{l}\text { - } \quad \text { complete multiple drafts of writing tasks } \\
\text { - } \text { rehearse and record speaking tasks } \\
\text { - } \quad \text { share, comment on, and revise speaking and writing tasks }\end{array}$ & 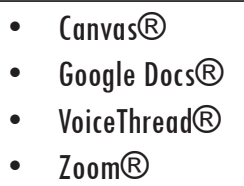 \\
\hline
\end{tabular}


in synchronous sessions. Critically, integration of appropriate technologies enables students to draw meaningful connections between texts and tasks, thereby fostering a move from primary discourse to secondary discourses (Gee, 1998) that is the hallmark of language development across the curriculum.

\section{There and Back Again: Returning to Classroom-based Instruction}

The GUGD transition from classroom-based instruction to DLE has at times been fraught, but it has also provided a fertile environment for instructional experimentation and curricular renewal. As we envision a return to classroom-based instruction, it is crucial to capitalize on the affordances that digital learning contexts can provide in the post-pandemic era (Guillén et al., 2020). Two principles often linked to such contexts, communication and collaboration, can help to determine the shape of foreign language instruction in the GUGD going forward.

The fact that instructors and students could maintain a level of face-to-face contact through the audiovisual platform Zoom $^{\bullet}$ was crucial to class cohesion and course coherence. When again seated together in a physical classroom, it will no longer be necessary to $\log$ on to Zoom ${ }^{\circ}$ to attend class; however, the chat functionality that $\mathrm{Zoom}^{\odot}$ enables in DLE should be preserved. For instance, students and instructors who are learning together in a classroom can simultaneously use a text chat program to support side conversations. So long as all students are able to $\log$ on easily and the comments are visible to all participants, this technology can foster a level of communication that expands upon the traditional discourse patterns of classroom communication.

Many instructors in the GUGD have found the use of Google Docs ${ }^{\bullet}$ facilitative for communication and collaboration. When linked to the completion of out-of-class work, students can seek assistance by initiating an asynchronous conversation with their instructor at the moment they have a question. Instructors benefit in that they can better grasp the particular struggles that individual learners face and offer targeted help. Given the pedagogical value of this "upgraded" interface for completing out-of-class work, the GUGD will seek to maintain a similar level of communication with students as they complete such work in course sections that are not intended for DLE. An additional benefit to this way of operating is a reduction in the quantity of paper used by students and instructors, thereby contributing to environmental sustainability efforts.

The use of a shared class Google Doc as a digital whiteboard and repository for course notes has proven to be an effective pedagogical strategy. Will such usage also be practical for classroombased instruction? The answer here is likely to involve a negotiation based on teacher and student preferences. While there are a number of advantages that come with using a "digital whiteboard," in a physical classroom, the teacher should also be free to move about and not feel tethered to a computer. Perhaps a solution to this tension would be to use both the classroom-based whiteboard together with a Google Doc. In such a scenario, it could become the purview of the students to carefully record the notes taken on the whiteboard and then transfer these notes to the Google Doc following class. The instructor can then monitor, clarify and confirm the students' entries, thereby providing a digital through-line between physical meetings of the class.

Recognizing that the technologies described herein are essential for DLE to function. We must also remain cognizant that sound pedagogical thinking and critical reflection are just as essential to the success of technology-enhanced classroom-based language instruction. This awareness should also acknowledge that an increasing reliance on technology presents a new set of problems we must grapple with. For example, whereas language curricula are generally designed with explicit reference to 
proficiency level, there is currently little thought as to how we can ensure a roughly equivalent level of technological proficiency among student cohorts across the curriculum. Similarly, our assessment practices must innovate to include the effective use of technology for communication and collaboration. Here, we can perhaps look for inspiration to practitioners of virtual exchange who have long tied evaluation of learning to not only language development and intercultural competence, but also to the growth of (critical) digital literacies (e.g. Helm \& Guth, 2010; Hauck, 2019).

In closing this report, it is hoped that the needs analysis, teacher education and pedagogical adjustments described herein can serve as a source of inspiration for language departments seeking to provide quality language instruction at a distance. Although the pandemic has caused tremendous hardship in the academic and personal lives of instructors and students, let us also hope that the pedagogical innovations it has triggered will lead to an enhanced relationship between language teaching and technology going forward.

\section{Acknowledgements}

I would like to express my profound gratitude to the faculty and graduate student instructors of the GUGD for the tremendous effort and good will that characterized our work during the COVID-19 pandemic. I also thank the anonymous reviewers and editors for their feedback on earlier drafts of the article. Any shortcomings or omissions are my own.

\section{References}

Adams, R., \& Nik, N. (2013). Prior knowledge and second language task production in text chat. In M. González-Lloret \& L. Ortega (Eds.), Technologymediated твLT: Researching technology and tasks. (pp.51-78). John Benjamins.

Appel, C. and Gilabert, R. (2002). Motivation and task performance in a task-based, web-based tandem project. ReCALL, 14(1), 16-31.
Blake, R. (2005). Bimodal chatting: The glue of a distance language learning course. CALICO Journal, 22, 497-511.

Blake, R. (2009). The use of technology for second language distance learning. The Modern Language Journal, 93, 822-835. https://doi. org/10.1111/j.1540-4781.2009.00975.x

Byrnes, H., Crane, C., Maxim, H., \& Sprang, C. (2006). Taking text to task: Issues and choice in curriculum construction. International Journal of Applied Linguistics, 52(1), 85-109.

Collentine, K. (2009). Learner use of holistic language units in multimodal, task- based synchronous computermediated communication. Language Learning and Technology, 13, 68-87.

Cope, C., \& Kalantzis, M. (2009). 'Multiliteracies': New literacies, new learning. Pedagogies, 4(3), 164-195.

Crane, C. (2006). Modelling a genre-based foreign language curriculum: staging advanced L2 learning. In $\mathrm{H}$. Byrnes (Ed.), Advanced language learning. The contribution of Halliday and Vygotsky (pp. 227-245). Continuum.

Cunningham, D. J. (2016). Request modification in synchronous computer-mediated communication: The role of focused instruction. The Modern Language Journal. 100(2), 484-507.

Cunningham, D. J. (2019). Telecollaboration for content and language learning: A genre-based approach. Language Learning \& Technology, 23(3), 161-177. https://www.lltjournal.org/item/3126

Cunningham, D. J., Pfeiffer, P. Ryshina-Pankova, M. (2018). Assessing humanities learning in an integrated undergraduate German curriculum. Die Unterrichtspraxis/Teaching German, 51(2), 144-155. https:// doi.org/10.1111/tger.12070

Cunningham, D. J. \& Ryshina-Pankova, M. (2020). What's with the attitude? Exploring attitudinal resources in telecollaboration for teacher education. In A. Oskoz \& M. Vinagre (Eds.), Understanding Attitude in intercultural virtual communication (pp. 144-165). Equinox.

Gee, J. P. (1998). What is literacy? In V. Zamel \& R. Spack (Eds.), Negotiating academic literacies: Teaching and learning across languages and cultures (pp. 51-59). Lawrence Erlbaum.

Georgetown University, Department of German. (2020) Undergraduate program: Curriculum. http://german.georgetown.edu/undergraduate/curriculum/ 
González-Lloret, M. (2014). The need for needs analysis in technology-mediated твLT. In M. González-Lloret \& L. Ortega (Eds.), Technology-mediated TBLT: Researching technology and tasks. (pp. 51-78). John Benjamins.

González-Lloret, M. \& Ortega, L. (2014). Towards technology-mediated TBLT: An introduction. In M. González-Lloret \& L. Ortega (Eds.), Technologymediated твLT: Researching technology and tasks. (pp. 1-22). John Benjamins.

Guichon, N. (2009). Training future language teachers to develop online tutors' competence through reflective analysis. $\operatorname{Re} C A L L, 21(2), 166-185$.

Guichon, N., \& Hauck, M. (2011). Teacher education research in CALL and CMC: More in demand than ever. ReCall, 23(3), 187-199.

Guillén, G., Sawin, T. \& Avineri, N. (2020). Zooming out of the crisis: Language and human collaboration. Foreign Language Annals, 53, 320-328. https://doi. org/10.1111/flan.12459

Hampel, R. (2006). Rethinking task design for the digital age: A framework for language teaching and learning in a synchronous online environment. ReCALL, 18(1), 105-121.

Hampel, R. (2009). Training teachers for the multimedia age: developing teacher expertise to enhance online learner interaction and collaboration. Innovation in Language Learning and Teaching, 3(1), 35-50.

Hampel, R. \&, de los Arcos, B. (2013). Interacting at a distance: A critical review of the role of ICT in developing the learner-context interface in a university language programme. Innovation in Language Learning and Teaching, 7(2), 158-178.

Hampel, R., \& Stickler, U. (2005). New skills for new classrooms: Training tutors to teach languages online. Computer Assisted Language Learning, 18(4), 311-326.

Helm, F., \& Guth, S. (2010). The multifarious goals of telecollaboration: Theoretical and practical implications. In F. Helm \& S. Guth (Eds.), Telecollaboration 2.0 language literacies and intercultural learning in the 21st Century (pp. 69-106). Peter Lang.

Hauck, M. (2019). Virtual exchange for (critical) digital literacy skills development. European Journal of Language Policy, 11(2) pp. 187-210. https://doi. org/10.3828/ejlp.2019.12

Hubbard, P. \& Levy, M. (Eds.) (2006) Teacher education in CALL. John Benjamins.
Jauregi, K., de Graaff, R., van den Bergh, H., \& Kriz, M. (2012). Native/non-native speaker interactions through video-web communication: A clue for enhancing motivation? Computer Assisted Language Learning, 25(1), 1-19.

Kitade, K. (2008). The role of offline metalanguage talk in asynchronous computer-mediated communication. Language Learning \& Technology, 12(1), 64-84.

Kraemer, A. (2008). Formats of distance learning. In S. Goertler \& P. P. Winke (Eds.), Opening doors through distance language education: Principles, perspectives and practices (pp. 11-42). CALICO.

Lamy, M.-N. (2004). Oral conversations online: Re- defining oral competence in synchronous environments. ReCALL, 16, 520-538.

Lamy, M.-N. (2006). Interactive task design: Metachat and the whole learner. In Garcia Mayo, P. (Ed.), Investigating tasks in formal language learning (pp. 242-264). Multilingual Matters.

Levy, M., \& Kennedy, C. (2004). A task-cycling pedagogy using audio-conferencing and stimulated reflection for language learning. Language Learning \& Technology, 8(2), 50-68.

Lewis, T., \& O’Dowd, R. (2016). Introduction to online intercultural exchange and this volume. In R. O'Dowd \& T. Lewis (Eds.), Online intercultural exchange: Policy, pedagogy, practice (pp. 3-20). Routledge.

Martin, J. R. (1984). Language, register and genre. In F. Christie (Ed.), Children writing: Reader (pp. 2129). Deakin University Press.

New London Group. (1996). A pedagogy of multiliteracies: Designing social futures. Harvard Educational Review, 66, 60-92.

Oskoz, A., \& Elola, I. (2014). Promoting foreign languge collaborative writing through the use of Web 2.0 tools and tasks. In M. González-Lloret \& L. Ortega (Eds.), Technology-mediated твLт: Researching technology and tasks (pp. 1-22). John Benjamins.

Paesani, K., Willis Allen, H., Dupuy, B. (2016). A multiliteracies framework for collegiate foreign language teaching. Pearson.

Rosell-Aguilar, F. (2005). Task design for audiographic conferencing: Promoting beginner oral interaction in distance language learning. Computer Assisted Language Learning, 18(5), 417-442.

Ryshina-Pankova, M. (2018). Discourse moves and intercultural communicative competence in telecollaborative chats. Language Learning \& Technology, 22(1), 218-239. 
White, C. J. (2017). Distance language teaching with technology. In C. A. Chapelle \& S. Sauro (Eds.), The handbook of technology and second language teaching and learning (pp. 134-148). Wiley Blackwell.
Yilmaz, Y. \& Granena, G. (2009). The effect of task type in synchronous computer-mediated communication. ReCALL, 22, 20-38. https://doi.org/10.1017/ S095834400999017

How to cite this article: Cunningham, D. J. (2021). Adapting an undergraduate multiliteracies German curriculum for online instruction during the Covid-19 pandemic. Íkala, Revista de Lenguaje y Cultura, 26(3), 749-765. https://doi.org/10.17533/udea.ikala.v26n3a15 
